\title{
Interactive Multimedia Learning Development for Third-Grade of Elementary School Students
}

\author{
Adrianus I W. I. Yuda Sukmana ${ }^{1}$, Ketut Pudjawan ${ }^{2}$, Desak Putu Parmithi ${ }^{3}$ \\ \{AIWIY-sukmana@undiksha.ac.id ${ }^{1}$, ketut.pudjawan@undiksha.ac.id² ${ }^{2}$ dp-parmiti@undiksha.ac.id ${ }^{3}$ \} \\ Universitas Pendidikan Ganesha, Indonesia ${ }^{123}$
}

\begin{abstract}
This is a development research aimed to produce an interactive multimedia learning technique for third-grade elementary school students. The development procedure made use of an ADDIE model. This study aims to analyze the responses of experts and a small group of students to multimedia. The questionnaire method was used to collect data. The product proved to be well qualified (98.5\%) when reviewed by a content expert, $90.6 \%$ when analyzed by a learning media expert, and $90.8 \%$ when examined by an instructional design expert. The results obtained from both groups shows that the interactive multimedia learning technique is super qualified ( the score is $93.9 \%$ and $94 \%)$.
\end{abstract}

Keywords: Multimedia, interactive learning multimedia, Mathematics

\section{Introduction}

Mathematics is an essential part of the education curriculum and one of the crucial subjects given to students irrespective of their educational level (elementary level to higher education). Mathematics is a means to develop students' cognitive abilities to enable them to think critically, logically, when solving various arithmetic and logic everyday problems. However, as a discipline that underlies the development of modern technology, many students find it difficult to assimilate this subject. Data collected by observing and analyzing elementary schools in the Singaraja city area shows that students are consistently faced with problems arising from the study of mathematics. Most students still see the subject as a difficult and horrific discipline. This problem is further strengthened by the limited learning tools capable of capturing and motivating student's interest. Most schools tend to make use of a particular mathematical learning tool in the form of textbooks with teachers applying conventional learning methods. This makes the subject less attractive to most students. However, the use of information and communication technology which happens to be in great demand by students has not yet been used as an alternative medium in teaching mathematics students.

According to Ashyar (2012), the low learning outcomes of mathematics can be influenced by various factors, such as students and teachers zeal to learn, the learning methods used, the availability of learning resources and media, and the surrounding environment process [2]. Based on the about listed factors, it can be said that the availability of relevant media and learning resources is one of the significant challenges faced in teaching and learning mathematics. Similarly, the obtained information shows that learning media posses similar 
features with the educational materials; however, supporting pleasant educational tools are currently unavailable. These findings come to be an essential consideration for developing innovative teaching tools in the form of interactive multimedia learning equipment to solve the numerous inconsistencies associated with teaching mathematics to third-grade students of elementary schools.

Learning media comprises of all that is required to teach. Asyhar (2012) explains that regarding psychology, it contains several functions, namely: 1) Attention, 2) Affective, 3) Cognitive, 4) Psychomotor, 5) Imaginative and 6) Motivational functions. However, various types and formats of media have been developed and used in learning. These media tools are grouped into four categories, namely visual-media, audio-media, audio-visual media, and multimedia [2].

In accordance with the ever revolving trends associated with the inception of the millennial age across the globe. Information technology has become a necessity in people's lives. Everything has become quite easy to achieve with unlimited use of the computer, computational devices, and data, and owing to the influence of digital technology [11]. Its impact can be seen in the rapid changes experienced in people's lives [5]. Technological advances and trends in developing countries have aided in the development of students lives, as they familiarize themselves with the computer and digital technology. Students in this region are motivated to learn and acquire knowledge as they find these digital devices attractive and easy to use. This also encourages the existence and use of computer-based learning media such as multimedia to teach students mathematics and other subjects.

Multimedia involves the integration of several types of media in the learning process. This teaching technique makes use of the sense of sight and hearing through text, static and dynamic visuals, audio media, and computer technology. In simple terms, Mayer (2009) defines multimedia as a medium that represents material in the form of words (verbal and nonverbal), and images ( static and dynamic) [6]. In its development stage, multimedia could be linear (runs sequentially without being controlled e.g., film and TV), or interactive (equipped with control devices for easy use) [7].

One of the advantages of using multimedia as an educational tool is its interactivity. This allows students to make their choices regarding the needed material in meaningful ways [10]. There are several similarities between multimedia and learning, this includes 1) it increases the interaction between teachers and students. 2) it helps teachers teach correctly. 3) it enhances student learning capacity [3]. Besides this, learning scenarios that are inserted in multimedia encourage students to think, explore, and develop initiative attitudes, generate interest in learning, and elaborate their learning initiatives, enthusiastic and creative process.

\section{Research Methods}

This study is development research aimed at creating a mathematical interactive multimedia learning tool for third-grade elementary school students. The development process refers to ADDIE model (analysis, design, development, implementation, evaluation). 


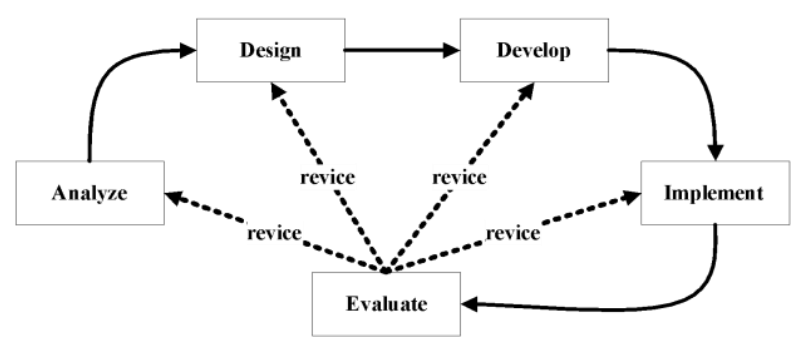

Fig 1. ADDIE Model (Source: Gagne, Wager, Golas, \& Keller, 2005)

The ADDIE model was chosen owing to its flexibility in the evaluation phase which was carried out on each ADDIE component to enable a more optimal tool. ADDIE model is an acronym that emerged from Analysis, Design, Development, Implementation, and Evaluation. In the analysis stage, the students' characteristics are used to determine the subjects and analyze the subjects, existing learning resources. The design phase is used to design the content frameworks, storyboards, interface, and media interactivity. The development stage is used to process and produce media materials into a single unit. In this stage, the product quality test is also carried out through content, learning media and learning design experts review. In addition, individual and small group testing was also conducted to determine product quality before it was implemented. In the implementation stage, the tool is applied to real learning process in a class of 31 students. The evaluation stage is used to evaluate the various phases to ensure optimal performance.

The subjects of this study comprised of: (1) the expert judgment stage, which is made up of learning content, instructional design and learning media experts. The learning content expert used in this study was a mathematics teacher who had more than 7 years of teaching experience. Instructional design and learning media experts were lecturers with master's degree in instructional technology; (2) at the individual responses stage, the subject of the study involved 3 fourth-grade elementary school students in SDK Karya Singaraja, (3) the small group responses phase involved 12 fourth-grade students from SDK Karya Singaraja.

This study uses the qualitative and quantitative descriptive analyses to analyze data. Qualitative descriptive data analysis techniques are used to manage data from reviews of content professionals, media, and instructional design and student responses of individual and small group tests in the form of responses and input from experts and students. Quantitative descriptive analysis is used to describe expert, and student assessments result using a Likert scale. The formula used to calculate the percentage of score given by research subject is as follows.

$$
\text { Percentage }=\frac{\sum(\text { Answer } \times \text { weight of choise })}{n \times \text { highest weight }} \times 100 \%
$$

\section{Description}

$$
\begin{aligned}
& \Sigma=\text { Total } \\
& \mathrm{n}=\text { Amount of all questionnaire items }
\end{aligned}
$$


The formula that used to calculate the percentage of entire subject is:

$$
\text { Percentage }=\frac{F}{n}
$$

\section{Description:}

$\mathrm{F} \quad=$ Total percentage of all subjects

$\mathrm{n} \quad=$ Amount of subjects

To be able to give meaning and decision making provisions as follows.

Table 1. Conversion of Rate of Achievement in Product Testing with Scale 5

\begin{tabular}{ccc}
\hline Level of Achievement & Qualification & Remarks \\
\hline $90 \%-100 \%$ & Very Well & No need to be revised \\
$75 \%-89 \%$ & Well & Little revised \\
$65 \%-74 \%$ & Enough & Revised sufficiently \\
$55 \%-64 \%$ & Less & Much revised matter \\
$0-54 \%$ & Very Less & Repeated produce \\
\hline
\end{tabular}

(Source: Tegeh \& Kirna, 2010)

\section{Results and Discussion}

\subsection{Results}

From a series of development processes that have been carried out following the product development path and in accordance with the ADDIE model, the product results can be seen below.

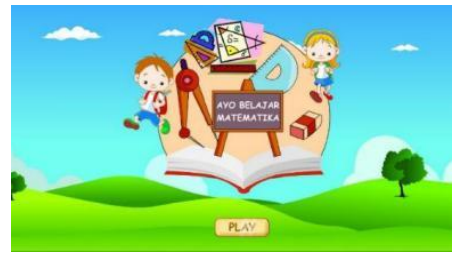

Fig 2: Display of Opening Pages / Introduction

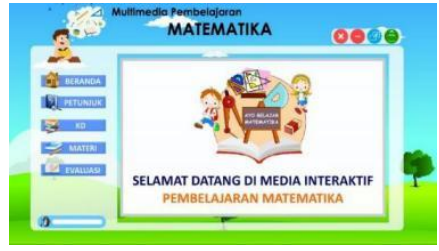

Fig 3: Display of Main Material Pages

To find out the quality of the product so that it can be implemented in the learning process significantly, a series of tests were conducted to measure the quality of the interactive learning multimedia for third-grade elementary school students in mathematics. This activity involves 
several tests, namely: 1) Experts Judgment test, 2) Individual Student Responses test, 3) Small Group Student Responses test. The results of tests can be seen in the table below. The Dataset can be accessed in osf.io/w6mxy Open Science Framework[1]

Table 2. Tabulation of Product Feasibility Test Results

\begin{tabular}{cccc}
\hline No. & Testing Stages of & Achievement Score & Qualification \\
\hline 1 & Product Review by Content Expert & $98.5 \%$ & Very Well \\
2 & Product Review by Learning Media Expert & $90.6 \%$ & Very Well \\
3 & Product Review by Learning Design Experts & $90.8 \%$ & Very Well \\
4 & Products Test by Individual Students & $93,9 \%$ & Very Well \\
5 & Products Test by Small Group Students & $94 \%$ & Very Well \\
\hline
\end{tabular}

\subsection{Discussion}

Based on the research that has been conducted at the individual testing stage, it is known that students feel happy and interested in learning mathematics when interactive learning multimedia is used. Students in a small group test also showed the same responses. Based on the questionnaire given, all students gave a positive response to the use of multimedia in teaching mathematics. They stated that they were happy and motivated to learn the subject using this tool. This finding is in line with Darmawan's opinion (2012) which said that the use of an interactive multimedia tool is capable of enhancing students desire to learn because it is a combination of text, audio, video, and animation [8]. Motivation is one of the essential elements of effective learning. It does not only play an indispensable role in getting students involved in the learning process, but it also determines the amount of information that can be processed by students. Students with higher motivation to learn will use their cognitive processes to learn and remember faster [9]. Therefore, a student's motivation to learn must be increased. Based on the results of individual and small group test, it can be concluded that multimedia motivates students to learn mathematics.

\section{Conclusion}

The Conclusions of this study are: (1) The interactive learning multimedia for third-grade elementary school students is developed according to the ADDIE Model. (2) Results of product review by Learning Content, Media, Design Expert, shows that the product is in very well quality. In addition, the Product Test by Individual and Small Group of Students shows the same making the product feasible to be implemented in the learning process

\section{References}

[1] A. I. W. I. Y. Sukmana.: "Dataset of Interactive Multimedia Learning Development for ThirdGrade of Elementary School Students," 06-Jan-2019. [Online]. Available: osf.io/w6mxy.

[2] Asyhar, R.: Kreatif mengembangkan media pembelajaran. Jakarta: Referensi Jakarta (2012)

[3] Chen, C. Y. \& Chung, W. L.: Research on the learning effects of multimedia assisted instruction on Mandarin vocabulary for Vietnamese students: a preliminary study involving e-learning system. Educational Research Reviews. 6(17): 919-927. Available at: http://www.academicjournals.org /err/PDF/Pdf\%202011/5Nov/Chen\%20and\% 20Chung.pdf (2011) 
[4] Gagne, R.M., Wager, W.W., Golas, K.C., \& Keller, J.M. : Principles of instructional design, 5th Ed. Belmont, CA: Wadsworth/Thomson Learning (2005)

[5] Hariastuti, R. T., Prawitasari, J. E., Handarini, D. M., Atmoko,A.: The Development of Critical Thinking Skills Based of Patrap Triloka's Ki Hadjar Dewantara. International Journal of Development Research. 7(7).13606-13611 (2017)

[6] Mayer, M. R.: Multimedia learning. Translated by Baroto Tavip Indrojarwo. Multimedia learning. Yogyakarta: Pustaka Pelajar (2009)

[7] Sigit, Bambang, \& Joko.: Pengembangan pembelajaran dengan menggunakan multimedia interaktif untuk pembelajaran yang berkualitas. Paper. Presented at Faculty level of scientific writing competition, April, 2nd-3rd, 2008 Placed in Universitas Negeri Semarang, Semarang (2008)

[8] Saputri, D. Y., Rukayah, Indriayu, M.: Need Assessment of Interactive Multimedia Based on Game in Elementary School: A Challenge into Learning in 21st Century. International Journal of Educational Research Review. doi :10.24331/ijere.411329 (2018)

[9] Slavin, R.E. : Psikologi Pendidikan: Teori dan Praktik. Jakarta: Indeks (2011)

[10] Smaldino, S. E., Deborah L. L \& James D. R.: Instructional Technology and Media for Learning. Jakarta: Kencana (2012)

[11] Subekti. H., taufiq, M., Susilo, H., Ibrohim, Suwono, H.: Mengembangkan Literasi Informasi Melalui Belajar Berbasis Kehidupan Terintegrasi Stem Untuk Menyiapkan Calon Guru Sains Dalam Menghadapi Era Revolusi Industri 4.0: Literature Review. Education and Human Development Journal. 3(1).81-90 (2018)

[12] Sudarsana, I K., Renawati. P. W. Nerta, I W., Poniman, Widana I K. A. Saddhono, K. Napitupulu, D.: The Effectiveness Of Multimedia Training For Elementary School Teachers In Karangasem, Bali. Journal of Physics:Conference Series, 1114, 012032. doi:10.1088/17426596/1114/1/012032 (2018)

[13] Tegeh, I M., \& Kirna, I M.: Pengembangan bahan ajar metode penelitian pengembangan pendidikan dengan ADDIE model. Laporan Penelitian. (tidak diterbitkan). Singaraja: Universitas Pendidikan Ganesha (2010)

[14] Weinert, L. V. C. \& Lopes, H. S.: Computer in physical therapy education: Interactive multimedia learning with MuStreT. Informatics in Education. 8(2). 157-172. Available at: http://www.mii.lt/informatics_in_education/pdf/INFE149.pdf (2009) 